\title{
Funding problems loom for new German institutes
}

Munich. Two more research institutes are to be opened in eastern Germany by the Max Planck Gesellschaft, the body which already runs 65 basic research institutes across the country. This will bring the total number of institutes in the new Länder to seven.

But Hans Zacher, president of the MPG, says that future expansion in eastern Germany could face difficulties if the funding mechanism set up to support it, due to expire at the end of 1994, is not extended.

At the beginning of next year, an institute for plant physiology will open in Potsdam, and one for the history of science in east Berlin. A further four - in neuropsycho$\operatorname{logy}$, theoretical biology, the enzymology of peptide binding and gravitational physics will be set up over the next two years.

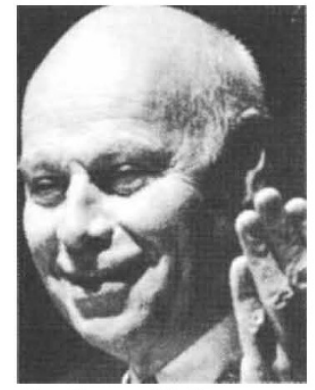

Zacher calls for extension of subsidy.
The big question now is how these new institutes will be funded. In the 11 'old' Länder, Max Planck institutes are supported equally by the federal and regional governments. Before reunification, all the money was pooled, so that the MPG was able to divide its money between institutes in different Länder free from political pressures.

Since reunification, the MPG's money has been divided into two pools, one for the east and one for the west. This has meant that the new Länder have not been required to contribute towards established institutes in the west, and have therefore been able to ensure that their money was being used to build up a research base in the east.

But if the situation reverts - as planned - at the end of next year, the new Länder will have to pay far more. At present, despite new openings, they still have proportionally far fewer institutes than the old Länder, and only pay for these. If they were thrown into the general pot, they would have to help pay for the western institutes as well.

Zacher claims that this would be unfair, and has asked the old Länder governments to accept the current system until at least 1996 , when their expansion programme is planned to be complete. But western Länder have proposed a compromise under which the new Länder would make up part of the difference between their current contribution and that which will eventually be due.

The MPG has been criticized by other research organizations for its relative slowness in establishing itself in east Germany.

The society denies the charge, pointing out that by the beginning of last year it had established 28 university research groups.

Its goal has been to help reintegrate research into universities of the former East Germany, whose Communist government had wanted to separate research from teaching. But this too is running into problems.

The agreement between the MPG and the universities required the universities to offer staff contracts to group leaders and some other researchers when the five years of MPG support runs out. But the groups have become too large for the universities to absorb all their members.

Zacher has said that support for scientists who have not been taken on to university payrolls will be extended until their projects are completed.

\section{Eastern Europe media accused of 'ignoring science'}

Geneva. The collapse of communist regimes in eastern Europe has led to a dramatic decline in the serious reporting of scientific topics in print and television media, a meeting of more than 200 science journalists at the European Laboratory for Particle Physics (CERN) was told last week.

To counter this trend, journalists from eastern Europe urged their Western colleagues to give greater publicity to the work of scientists from the former communist countries. Only in this way would scientists receive attention from their own media.

Under the communist regimes, science journalists were strongly supported by the state, partly because political ideology stressed the importance of science education. Extensive science coverage in communist newspapers, radio and television attracted a wide and loyal following; one reason, according to Jiri Grygar, the presenter of a Czech science television show, is that science was seen as the only area of truth in a sea of political propaganda.

Today, however, science journalists find it even harder to convince editors in the new market economies of the value of reporting scientific news - particularly if the science is carried out in their own countries - than their western counterparts.

Viola Egykova, from Moskovskaya Pravda, says that 'pseudoscience' has taken the place of real science. Editors find plenty of space for "the speculations of sorcerers, astrologers and phoney prophets", she says. One explanation for this popularity, says István Palugyai from the Budapest-based newspaper Népszabadság, is that because the parasciences were forbidden in communist times, people believe they must be true.

Alison Abbott

\section{Survey shows concern about biotechnology continues to grow}

Paris. Public support for biotechnology has dropped sharply in member states of the European Union (EU) over the past two years, a European Commission survey has found. But the so-called Eurobarometer survey of 12,800 Europeans also shows that the majority remain optimistic about new technology in general.

More than 80 per cent of those questioned thought that telecommunications and solar energy would make life better over the next 20 years. Almost three-quarters felt similarly about information technology and new materials, but only 42 per cent about space exploration.

The pattern is consistent with the findings of the previous survey, carried out in 1991. Optimism has dropped slightly, per- haps due to a perception that unemployment in Europe is rising as a direct consequence of new technology's destruction of jobs.

Two years ago, 71 per cent thought that biotechnology and genetic engineering would make life better. Today only 65 per cent do. Moreover, 20 per cent feel these areas will make life worse, compared to only 16 per cent in 1991 .

The fall is even more marked in Germany, where only 45 per cent think biotechnology will improve life, compared with 59 per cent in 1991. The proportion of those who think it will make life worse has jumped from 16 to 28 per cent over this period.

The survey reveals that public awareness of the risks of various biotechnological applications has increased in all fields except animal breeding, where it was already high. Moreover, the increase is linked to reduced willingness to support research, apart from medicine.

Most of those questioned, however, agreed that biotechnology research is "worthwhile and should be encouraged" (except for research on farm animals, and to a lesser extent, on food). More than three-quarters believe that ethical guidelines are needed.

Mark Cantley, head of biotechnology at the Organization for Economic Cooperation and Development (OECD), says that the results from the Netherlands are particularly disturbing. Public acceptance has continued to fall despite a highly organized information campaign on biotechnology.

Declan Butler 